\title{
CHRZEŚCIJAŃSKA IDEA MĘCZEŃSTWA
}

Intencją niniejszego artykułu nie jest bynajmniej przedstawienie całości doktryny chrześcijańskiej na temat męczeństwa. Chodzi w nim raczej o uchwycenie jej zasadniczych zrębów w aspekcie dynamicznym (rozwojowym), tzn. usiłuje on nie tylko naszkicować pojęcie męczeństwa, lecz również zobrazować próby poszerzenia go, przedstawić źródła, z których się wywodzi oraz ustalić miejsce, jakie zajmuje w Kościele.

W pierwszym rzędzie zostanie rozpatrzone pojęcie męczeństwa, które Kościół uważa za własne. Po opisaniu głównych jego elementów, zostaną omówione: męczeństwo duchowe i męczeństwo żołnierzy poległych na wojnie, jako próba poszerzenia właściwej idei męczeństwa.

\section{POJĘCIE MĘCZEŃSTWA}

Wydaje się że Orygenes w swoim komentarzu do Ewangelii św. Jana dobrze uchwycił sens męczeństwa chrześcijańskiego. Zdaniem jego każdy, kto składa świadectwo prawdzie, niezależnie od tego, czy tego dokazuje przez słowa, czynem lub w jakikolwiek inny sposób, słusznie może być nazywamy świadkiem. Stało się bowiem zwyczajem u braci - dzięki podziwowi dla tych, którzy walczyli aż do śmierci dla prawdy lub niewinności - nazywać świadkiem (męczennikiem) w pełnym znaczeniu tego słowa wyłącznie ludzi, którzy wylewając krew oddali świadectwo

* Por. pracę doktorską autora obronioną 1. II. 1967 r. na Uniwersytecie Gregoriańskim w Rzymie i opublikowaną drukiem wiosną 1968 r. w języku francuskim: A. KUBIS, La théologie du martyre au vingtième siècle (Pontificia Universitas Gregoriana. Facultas Theologica), Roma, 1968, zwłaszcza ss. 41-85; 178-181; 205. 
tajemnicy wiary. Zbawiciel jednak uważa za świadka każdego, kto świadczy o Jego nauce ${ }^{1}$.

Poglądy współczesnych autorów na temat męczeństwa pokrywają się całkowicie z tymi słowami. Na przykład $R$. Reitzenstein tak pisze na temat męczeństwa św. Polikarpa i męczeństwa przedstawianego w całej patrystyce: człowieka, który umarł za Chrystusa nazywano martys tou Christou albo martys tou theou; śmierć była uważana za martyria lub martyrion; ponieść śmierć określano jako martyresai. ${ }^{2}$ Podobną opinię reprezentuje $H$. Leclercq. Zacytowawszy osiem urywków z opisu męczeństwa św. Polikarpa stwierdza on, że nie można już kwestionować sensu słowa męczennik, oznaczającego śmierć poniesioną za wiarę. W tym znaczeniu termin męczeństwo wszedł do słownictwa chrześcijan. Posługują się nim także pisarze, których dzieła znane są tylko Kościołom lokalnym ${ }^{3}$. W rozumieniu F. Paschke do męczenników należą święci, którzy wiarę w Chrystusa poświadczyli śmiercią ${ }^{4}$. Nie inny sens ma również tłumaczenie słowa męczennik w językach Bliskiego Wschodu. Od samego początku - zauważa w tym względzie P. Peeters - jak tylko męczennik wszedł do najstarszych języków wschodnich, oznaczał on tam zawsze człowieka umierającego za wiarę, nic ponadto ${ }^{5}$. Wynika

1 Origéne, Commentaire sur saint Jean II, 210: SourcesChr 120, 351. - Lecz już „Clément d'Alexandrie (vers 216) prélude pour ainsi dire à la théologie du martyre. Bien qu'il veuille montrer qu'il existe un martyre spirituel, consistant dans une vie pure, néanmoins l'analogie qu'il établit entre le chrétien parfait et le martyr montre assez qu'au sens propre la mort est regardée comme inhérente au concept de martyre", E. Hocedez, Le concept de martyr, w: Nouvelle revue théologique, 55 (1928) 90.

2 R. Reitzenstein, Bemerkungen zur Martyrienliteratur. I. Die Bezeichnung Märtyrer, w: Nachrichten von der königlichen Gesellschaft der Wissenschaften zu Göttingen. Philologisch-historische Klasse, 3 (1916) 421. — Por. tamże, ss. 418-419; $442-445$.

3 H. Leclercq, Saint, w: Dictionnaire d'archéologie chrétienne et de liturgie, $15(1950) 389$.

4 F. Paschke, Märtyrer, w: Die Religion in Geschichte und Gegenwart, $4\left({ }^{3} 1960\right)$ 588. - Wielu autorów jest tego samego zdania. - Por. F. Kattenbusch, Der Märtyrertitel, w: Zeitschrift für die neutestamentliche Wissenschaft und die Kunde der älteren Kirche, 4 (1903) 111. - A. Kranich, Ist Kriegertod Märtyrertod?, w: Das ermländische Pastoralblatt, (1917) 2-3. - M. Rackl, Ist der Tod fürs Vaterland ein Martyrium? (Separatabdruck aus der christlichen Schule 8. Jahrgang, 1917, Heft, 4), Eichstätt, 1917, ss. 9-14. - P. Allard, Dix leçons sur le martyre, Paris, ${ }^{7} 1930$, s. 7. Tenże, Martyre, w: Dictionnaire apologétique de la foi catholique, 3 (1926) 337. - P. Corssen, Begriff und Wesen des Märtyrers in der alten Kirche, w: Neue Jahrbücher für das klassische Altertum und Pädagogik, 35 (1915) 481; 484; 487; 492. Tenże, Über die Bildung und Bedeutung der Komposita Pseudoprofétēs, Pseudómantis, Pseudómartys. Eine Erwiderung, w: Sokrates, 72 (1918) 113. - G. Krüger, Zur Frage nach der Entstehung des Märtyrertitels, w: Zeitschrift für die neutestamentliche Wissenschaft und die Kunde der älteren Kirche, 17 (1916) 268. - F. Dornseiff, Der Märturer: Name und Bewertung, w: Archiv Für Religionswissenschaft, 22 (1923-1924) 149. - E. Peterson, Martirio e martire, w: Enciclopedia cattolica, 8 (1952) 234-236. - M. Schmaus, Katholische Dogmatik, Bd. IV/1: Die Lehre von den Sakramenten, München, 51957, ss. 174-175.

5 P. Peeters, Les traditions orientales du mot martyr. Note complémentaire à l'article précédent, w: Analecta Bollandiana, 39 (1921) 53-54. - M. Lot-Borodine 
stąd, że dwa czynniki tworzą istotę męczeństwa w ujęciu chrześcijańskim, a mianowicie: świadectwo publicznie złożone Chrystusowi 6 i śmierć świadomie i dobrowolnie przyjęta, aby je potwierdzić ${ }^{7}$. Są one przy tym jednakowo konieczne, to znaczy, że bez nich nie ma po prostu chrześcijańskiej idei męczeństwa.

Mimo wszystko nie wolno zapominać o decydującej roli przedmiotu (treści) świadectwa składanego przez męczenników. Znane są bowiem słowa św. Augustyna o tej kwestii: „Powód (przyczyna), a nie sama kara czynią z ludzi męczenników" ". Męczennicy chrześcijańscy powinni świadczyć o Jezusie z Nazaretu ukrzyżowanym i zmartwychwstałym, dalej żywym, który „przyjdzie sądzić żywych i umarłych”. W konsekwencji świadczą oni o Objawieniu Bożym w Słowie, które się stało Ciałem, tzn. o drugim przymierzu, wypełnieniu prawa (telos) będącego początkiem i ukoronowaniem pierwszego ${ }^{9}$. A zatem, Jezus Chrystus,

opowiada się jednak za istnieniem różnic doktrynalnych na temat męczeństwa u Greków i w Kościele zachodnim: Appendice. Les deux aspects iconographiques du martyre chrétien en Orient et en Occident, w: Irénikon, 27 (1957) 167. - Por. tamże, s. 168. - Warto jeszcze zasygnalizować oryginalną koncepcję rosyjską męczeństwa. „Die alten hagiographischen Dokumente zeugen für das Bestehen eines neuen Märtyrer-Ideals im religiösen Bewusstsein des russischen Volkes. Nicht nur der Christ, der seinen Glauben vor dem Richterstuhl der Heiden oder der Ketzer bis zum Tode bekennt, gilt als Märtyrer, sondern jeder, der unschuldig leidet und widerstandlos den Tod auf sich nimmt, um so Christus 'gleichförmig' zu werden. Als 'Sstrasstoterpez' gilt, wer eine Passion erduldet, wer durch seine Sanftmut und Unterwerfung, seinen Sieg über die Liebe zum Leben und zur Welt dem Erlöser ähnlich wird in der liebe zu Gott und den Menschen. Ganz wie die Kinder von Bethlehem bekennt er das Fleischgewordene Wort ,non loquendo sed moriendo'", T. Kologriwow, Das andere Russland. Versuch einer Darstellung des Wesens und der Eigenart russischer Heiligkeit, München, 1958, ss. 32-33.

6 E. Peterson, Zeuge der Wahrheit (Die Offenbarung und der Märtyrer), w: Tenże, Theologische Traktate, Münschen, 1951, ss. 188-189. - Por. W. Schöllgen, Aktuelle Moralprobleme, Düsseldorf, 1955, s. 469.

7 W. Hellmans, Wertschätzung des Martyriums als eines Rechtfertigungsmittels in der altchristlichen Kirche bis zum Anfange des vierten Jahrhunderts (Inaugural-Dissertation), Breslau, 1912, ss. 4-6. - Por. J. Pohle, Soldatentod und Märtyrertod. Eine neue Untersuchung mit besonderer Berücksichtigung der Lehre des hl. Thomas von Aquin. Zugleich ein Beitrag zur Theorie des Martyriums, Paderborn, 1918, ss. 3-15; 16-25; 51-80. - H. Hedde, Martyre, w: Dictionnaire de théologie catholique, 10 (1928) 222; 225; 229. - P. Lumbreras, De fortitudine et temperantia (Praelectiones scholasticae in secundam partem D. Thomae, 11), Romae, 1939, ss. 24-28. J. E. Sherman, The Nature of Martyrdom. A Dogmatic and Moral Analysis to the Teaching of St. Thomas Aquinas (A Dissertation), Paterson, 1942, ss. 118-134; $145-181$.

8 "Martyres non facit poena sed causa”, S. Augustinus, Enarrationes in Ps. 34: $P L$ 36, 340. - Innymi słowy, ,nicht die Todesart und die Todesqual, sondern der objektive Todesanlass und die subjektive Absicht sind die ausschlaggebenden Momente des echten Martyriums", Pohle, Soldatentod und Märtyrertod, s. 117. Por. tamże, ss. 118-120. - Corssen, Begriff und Wesen des Märtyrers in der altchristlichen Kirche, s. 481. - Rack1, Ist der Tod fürs Vaterland ein Martyrium?, ss. 20-24. - Z tego względu nie można się zgodzić z E. Esking, który twierdzi, że w katolickiej koncepcji męczeństwa śmierć jest ważniejsza, niż wyznanie wiary: Das Martyrium als theologisch-exegetisches Problem, w: In memoriam Ernst Lohmeyer, wyd. W. Schmauch, Stuttgart, 1951, s. 225.

$9 \mathrm{H}$. W. Surkau, Martyrien in jüdischer und frühchristlicher Zeit (Forschungen zur Religion und Literatur des A. und des N. Testaments, 54), Göttingen, 1938, 
nie tylko Jezus historyczny, lecz również Pan obecnie żywy i zasiadający po prawicy Ojca, ,,pełny mocy Syn Boży” (Rz 1, 4) stanowi przedmiot świadectwa złożonego przez męczenników. Męczennik oddaje życie nie tylko za naukę Jezusa, lecz również za Jego osobę, z którą czuje się zjednoczony przez liczne więzy pobożności i miłości 10. Nadto należy jeszcze przypomnieć opinię św. Tomasza z Akwintu powszechnie przyjętą przez teologów, że cierpi się dla Chrystusa zarówno wtedy kiedy to się dzieje $\mathrm{z}$ powodu wiary $\mathrm{w}$ niego jak i wtedy, gdy jest się prześladowanym ze względu na dobre uczynki świadczone z miłości ku Niemu ${ }^{11}$. Swiadectwo złożone Chrystusowi obejmuje więc tak sprawy wiary jak i moralności 12. Nie może więc zostać nazwany męczennikiem ten, kto oddaje świadectwo jakiejkolwiek prawdzie, lecz tylko dający świadectwo prawdzie Bożej - inaczej doszłoby do absurdu. Musiałoby się uznać za męczennika np. człowieka, który umarł za jakąś prawdę geometryczną lub teorię filozoficzną ${ }^{13}$. $\mathrm{Z}$ drugiej strony nie tylko sama wiara może być przyczyną męczeństwa, lecz również każda cnota mająca związek z Bogiem, bo przecież dzieła cnót, o ile odnoszą się do Boga, są pewnym rodzajem wyznania wiary. Wiara bowiem naucza, czego Bóg żąda od ludzi i jak ich wynagradza za czyny ${ }^{14}$.

Ponadto oddając świadectwo, męczennicy pozostają pod wpływem działania Ducha Sw. Zdaniem M. Villera wpływ ten nie ulega najmniejszej wątpliwości. Normalnie pozostaje on wewnętrzny i tajemniczy. Istnieją jednak wypadki w historii męczeństwa chrześcijan, w których dostrzec go można w całej okazałości ${ }^{15}$. Duch Sw. udzielał im rad w chwilach próby. Nic więc dziwnego, że wierni uważali ciało męczenników za mieszkanie Ducha Sw., a ich samych za jego nosicieli ${ }^{16}$.

Ss. 139-140. - Por. Rackl, Ist der Tod fürs Vaterland ein Martyrium?, ss. 10-12. $\mathrm{E}$. Barbotin, Le témoignage spirituel (Thèse pour le doctorat en théologie), Paris, 1964 , ss. $248-249$.

10 M. Lods, Confesseurs et martyrs. Successeurs des prophètes dans l'Église des trois premiers siècles (Cahiers théologiques, 41), Neuchâtel-Paris, 1958, ss. 22-24. - Por. Pohle, Soldatentod und Märtyrertod, s. 27.

11 S. Thomas, Super Epistolam ad Romanos lectura, c. 8, lec. 7, w: S. Thomas Aquinas, Super Epistolas S. Pauli lectura (ed. VIII revisa cura P. Raphaelis Cai), vol. 1 (Taurini-Romae, 1953), s. 131.

12 Pohle, Soldatentod und Märtyrertod, ss. 31-33.

13 S. Thomas, Sum. theol., II-II, q. 124, a. 5, ad 2.

14 S. Thomas, In IV Sent., d. 49, q. 5, a. 3, qla 2, ad 11 i ad 12 . - Por. Hellmanns, Wertschätzung des Martyriums als eines Rechtfertigungsmittels in der altchristlichen Kirche, ss. 5-6. - Kranich, Ist Kriegertod Märtyrertod?, ss. 23-27; 35-36. - Pohle, Soldatentod und Märtyrertod, ss. 26-50; 108-134. - Hedde, Martyre, ss. 225-227. - Lumbreras, De fortitudine et temperantia, ss. 23-33. Sherman, The Nature of Matyrdom, ss. 57-92. - D. Ruiz Bueno, Actas de los mártyres (Biblioteca de autores cristianos, 75), Madrid, 1951, ss. 3-67.

15 M. Viller, Les martyrs et l'Esprit, w: Recherches de science religieuse, 14 (1924) 544-551.

16 F. J. Dölger, Gladiatorenblut und Märtyrerblut. Eine Szene der Passio Perpetuae in kultur-und religionsgeschichtlicher Beleuchtung, w: Vorträge 1923-1924 (Vorträge der Bibliothek Warburg, wyd. F. SAXL), Leipzig-Berlin, 1926, s. 213. - 
Za A. P. Frutazem można zatem powiedzieć, że w dzisiejszym języku chrześcijan męczennikiem jest ten, kto poświęcił swoje życie za Chrystusa, tzn. dla rzeczywistości lub prawdy wchodzącej w skład Objawienia chrześcijańskiego (dla obrony wiary, cnoty chrześcijańskiej, np. czystości, tajemnicy spowiedzi lub praw i jedności Kościoła) i że ta idea świadka zbroczonego krwią boskości Chrystusa i jego religii, wspieranego siłą nadprzyrodzoną, chociaż została sprecyzowana już w II wieku, to jednak aż do dziś stanowi jedyne określenie męczeństwa uznane przez Kościół za autentyczne ${ }^{17}$.

Co więcej, opisana idea męczeństwa zgodna jest $\mathrm{z}$ tą, jaka zarysowuje się na kartach Pisma św. ${ }^{18}$. Oczywiście, twierdzenie to nie oznacza, że w Piśmie św. znajduje się gotowe, wykończone w szczegółach pojęcie męczeństwa. W rzeczywistości bowiem - zauważa słusznie W. Derouaux - człowiek, który dla wyznania swej wiary w bóstwo Jezusa Chrystusa przelewa krew, jest równocześnie świadkiem i bohaterem, naśladowcą doskonałym Mistrza, pierwszego męczennika, i ofiarą, która składa życie za grzechy; cudem łaski nadprzyrodzonej i przykładem danym światu i braciom w wierze; wybrańcem, który się zbawia i pośrednikiem u Boga. W świetle tego, co wyżej zostało przytoczone, jest chyba normalnym prawem psychologii, że te kolejne aspekty odnośnie idei męczeństwa były odkrywane stopniowo. Fakt ten nie powinien dziwić ani niepokoić ${ }^{19}$. $\mathrm{Z}$ tego też względu nie można się zgodzić z tezą H. F. von Campenhausena, która zarzuca Kościołowi deformację pierwotnej, czystej idei męczeństwa. Według niego, pierwotna idea męczeństwa, nierozerwalnie związana z osobą Jezusa, Jego przyjściem, przepowiadaniem i śmiercią, poczęła powoli ulegać deformacji. Kościół Katolicki nawet całkowicie ją zniekształcił. Dopiero Reformacja waloryzując rolę słowa Bożego, przywróciła męczeństwu należne mu miejsce jako świadectu, które zostało oddane przepowiadaniu Chrystusa ${ }^{20}$. Teza powyższa nie jest prawdziwa.

Por. L. Cerfaux, Témoins du Christ (d'après le Livre des Actes), w: Angelicum, 20 (1943) 173-176. - R. Asting, Die Verkündigung des Wortes im Urchristentum. Dargestellt an den Begriffen „Wort Gottes”, „Evangelium” und „Zeugnis”, Stuttgart, 1939 , s. 705.

17 A. P. Frutaz, Martyrer, w: Lexikon für Theologie und Kirche, 7 (219,62) $127-129$.

18 Najlepsza prace na ten temat napisał E. Peterson, Apostel und Zeuge Christi. Auslegung des Philipperbriefes, Freiburg i. Br., 1940. - Por. H. Strathmann, Mártys, w: Theologisches Wörterbuch zum Neuen Testament, 4 (1942) 513-514. - Esking, Das Martyrium als theologisch-exegetisches Problem, s. 225. - D. Barsotti, Il martirio nella S. Scrittura, w: Humanitas, 10 (1955) 317-326.

19 W. Derouaux, Recenzja dzieła H. F. von Campenhausena, Die Idee des Martyriums in der alten Kirche, w: Analecta Bollandiana, 55 (1937) 359.

20 H. F. von Campenhausen, Die Idee des Martyriums in der alten Kirche, Göttingen, 21964 , ss. 1; 5; 174-175. - Oprócz recenzji wspomnianej w przypisku 19-tym warto w tej kwestii przekonsultować: J. de Ghellinck, Recenzja dzieła H. F. von Campenhausena, Die Idee des Martyriums in der alten Kirche, w: Nouvelle revue théologique, 64 (1937) 416-417. - R. Grosche, Pilgernde Kirche, Freiburg i. Br., 1938, s. 200. 
Z faktu bowiem, że Kościół stopniowo zdobywał pełnię swej świadomości o męczeństwie nie wynika, iż na tej drodze zdradził jego ideę pierwotną. Kościół tylko systematycznie gromadził owoce pracy, która się dokonała na przestrzeni stuleci.

Historia Kościoła jednakże zna próby poszerzenia właściwej idei męczeństwa. W związku z nimi trzeba będzie rozważyć problem ,męczeństwa duchowego" i „męczeństwa” żołnierzy chrześcijan 21. Pierwszy był już znany Ojcom Kościoła, drugi zaś ze szczególnym nasileniem był dyskutowany w czasie I wojny światowej (1914-1918).

\section{MĘCZEŃSTWO DUCHOWE}

Co należałoby rozumieć przez męczeństwo duchowe? ${ }^{22}$ Chodzi tutaj o naukę o podwójnym męczeństwie, która powstała w Kościele dzięki ascezie chrześcijańskiej i przepowiadaniu ${ }^{23}$. Otóż, obok męczeństwa krwawego tych, którzy oddali swoje życie za wiarę - zauważa M. Viller - istnieje bezkrwawe męczeństwo wiernych, którzy bez zastrzeżeń spełniają rady Mistrza; obok męczeństwa jednorazowego, które spełnia ofiarę, istnieje męczeństwo codzienne, trwające przez całe życie; obok męczeństwa publicznego, które dokonuje się zewnętrznie, na oczach wielu, istnieje męczeństwo ukryte w tajnikach świadomości; męczeństwo ciała i męczeństwo ducha ${ }^{24}$. Ta doktryna, ostatecznie sformułowana przez świętego Grzegorza Wielkiego należy w Kościele do bardzo starych ${ }^{25}$. Przez trzy pierwsze wieki chrześcijaństwa mówiono o męczeństwie ,zastępczym" porównując je z ascezą. Na Wschodzie (Klemens Aleksandryjski, Orygenes) jak i na Zachodzie (Tertulian, Cyprian, Komodian) przyrównywano męczeństwo do wysiłków koniecznych do nabycia cnoty, w szczególności cnoty czystości. Przygotowanie do męczeństwa, pragnie-

21 Wśród teologów dyskutowano również, czy można nazwać męczennikami N. M. P., św. Józefa, Niewinnych Młodzianków, Dobrego Łotra na krzyżu i osoby, które zmarły na skutek pielęgnacji zakaźnie chorych. M. Rackl, Die Anschauung der katholischen Theologen über das Martyrium des Soldatentodes, w: Divus Thomas, 8 (1921) 62-67. - Por. Hedde, Martyre, ss. 223-225.

22 H. Hedde mówi o męczeństwie ,przez analogię”, Martyre, s. 222.

23 U Irlandczyków istniała teoria o potrójnym męczeństwie. Obok męczeństwa czerwonego, męczeństwa rzeczywistego i krwawego, rozróżniano męczeństwa innych kolorów: męczeństwo białe, które utożsamiano najezęściej $\mathrm{z}$ zachowaniem cnoty czystości i męczeństwo zielone realizujące się $w$ aktach umartwienia podjętych dla pokuty za grzechy. Ten ostatni rodzaj męczeństwa był znany tylko Irlandczykom. L. Gougaud, Les conceptions du martyre chez les Irlandais, w: Revue bénédictine, 24 (1907) 360-374. - Por. J. Ryan, Irish Monasticism. Origins and Early Development, London-New York-Toronto, 1931, ss. 197-198; 283; 400. - M. Viller-K. Rahner, Aszese und Mystik in der Väterzeit, Freiburg i. Br., 1939, s. 40.

24 M. Viller, Le martyre et l'ascèse, w: Revue d'ascétique et de mystique, 6 (1925) 140-141. - Por. Kubiś, La théologie du martyre au vingtième siècle, s. 51, przyp. 24.

25 S. Gregorius, Hom. 33 in Evangel.: PL 76, 1263. - Por. tenże, Dial. 3, 2 : PL 57, 281. - Viller, Le martyre et l'ascèse, s. 141, przyp. 144. 
nie męczeństwa, równało się prawie męczeństwu realnemu i krwawemu ${ }^{26}$. Kiedy prześladowania skończyły się (313 r.), za męczeństwo duchowe uznano przede wszystkim życie monastyczne. Wszyscy, którzy mówią w tym czasie o mnichach, przyrównują ich również do męczenników - w ich oczach mnisi są następcami męczenników ${ }^{27}$. Twierdząc zatem, że partystyczna tradycja chrześcijańska uważała życie ascetyczne i monastyczne za męczeństwo, nie ryzykuje się pomyłki ${ }^{28}$.

Zdaniem H. F. von Campenhansena poglądami powyższymi idea męczeństwa chrześcijańksiego nie tylko zakończyła swój rozwój, lecz one oznaczają również jej dekadencję ${ }^{29}$. Wydaje się jednak, że nie jest to pogląd całkowicie słuszny. Idea męczeństwa duchowego zawiera z całą pewnością niektóre elementy istotne dla męczeństwa krwawego, tj. męczeństwa we właściwym znaczeniu tego słowa. Prawdziwa bowiem wartość męczeństwa polega na całkowitym oddaniu siebie w świadectwie. I właśnie ów całkowity dar z siebie ma miejsce w życiu chrześcijańskim zgodnym z wiarą. Tym bardziej, że środowisko, w którym żyją chrześcijanie dzisiaj, często pogańskie i przesycone pesymizmem, żąda od nich świadczenia, tzn. postępowania wbrew opiniom i utartym zwyczajom. Wymaga to częstokroć dużej ofiary. Taka właśnie postawa męczeństwa przez miłość stanowi też istotę nauki ewangelicznej ${ }^{30}$.

\section{MĘCZEŃSTWO ŻOENIERZY POLEGEYCH NA WOJNIE}

Śmierć żołnierzy, którzy giną na froncie stanowi z całą pewnością najwyższą ofiarę, jaką człowiek może złożyć. Czy jednak zasługuje ona również na miano męczeństwa? Czy jest prawdą, że krew wylana za ojczyznę sprawia, na wzór prawdziwego męczeństwa poniesionego za Chrystusa, odpuszczenie grzechów i natychmiastowy dostęp duszy do nieba? Innymi słowy, czy ofiara żołnierza chrześcijańskiego może zostać podniesiona $\mathrm{z}$ teologicznego punktu widzienia do godności męczeństwa. Otóż, zdania teologów w tym względzie są bardzo podzielone ${ }^{31}$.

26 Viller, Le martyre et l'ascèse, ss. 105-115. - F. E. Malone, The Monk and the Martyr. The Monk as the Successor of the Martyr (A Dissertation), Washington, 1950 , ss. $1-43$.

27 Viller, Le martyre et l'ascèse, ss. 115-135. - Malone, The Monk and the Martyr, ss. 44-143. - U. Ranke-Heinemann, Das frühe Mönchtum. Seine Motive nach den Selbstzeugnissen, Essen, 1944, ss. 95-100; 129-143.

23 A. Stolz, L'ascèse chrétienne, Chevetogne, 1948, s. 123. - Por. tamże, ss. $120-143$.

${ }_{29}$ Campenhausen, Die Idee des Martyriums in der alten Kirche, s. 144.

30 P. Lucien-Marie de Saint-Joseph, Le martyre d'amour, w: Limites de l'humain (Les études carmélitaines), Paris, 1953, s. 339. - Por. tamże, ss. 336-338.

31 Rackl, Die Anschauung der katholischen Theologen über das Martyrium des Soldatentodes, ss. 69-76. - A. Kleber, A Soldier's Death, a Martyrdom?, w: The American Ecclesiastical Review, 111 (1944) 281-290. - D. J. Saunders, The Supernatural Value of a Soldier's Death, w: Theological Studies, 6 (1945) 35-50. 
Teologowie niemieccy, jak M. Rackl ${ }^{32}$ A. Kranich ${ }^{33}$ i J. Pohle ${ }^{34}$ uznają śmierć żołnierzy poległych na polu chwały - oczywiście pod pewnymi warunkami - za prawdziwe męczeństwo chrześcijańskie ${ }^{35}$. Teologowie ci odwołują się do autorytetu św. Tomasza z Akwintu, który twierdzi, że każde dobro ludzkie, o ile ma odniesienie do Boga, może stać się przyczyną męczeństwa ${ }^{36}$. Poglądy ich nadto idą po linii rozumowania M. Lutra, który męczennikami ogłaszał nie tylko ludzi spalonych na stosie, lecz także żołnierzy poległych z bronią w ręku na wojnie przeciw Turcji ${ }^{37}$. We Francji kwestia ta podobnie interesowała teologów, lecz twierdzenia ich wydają się mniej kategoryczne. Precyzując naukę św. Tomasza z Akwinu na ten temat A. Michel pisze, że roztropność doktora Anielskiego, opierająca się na roztropności Kościoła, powinna określać naszą postawę. Choćby nawet było możliwe dla żołnierza na polu chwały stać się rzeczywistym męczennikiem, to możliwość ta wydaje się być ograniczoną do wypadków bardzo specjalnych i tak uwarunkowana, iż należy strzec się przed wszelką próbą uogólniania. Jeżeli w tej kwestii ma miejsce jakaś nadzieja, to nie trzeba jej czerpać z mało prawdopodobnego podobieństwa śmierci żołnierza do męczeństwa chrześcijańskiego, lecz z pewnej doktryny o usprawiedliwieniu pozasakramentalnym przez akt miłości doskonałej ${ }^{38}$. Zresztą, wielka ilość teologów posługujących się językiem francuskim, nie przyznaje tytułu męczennika żołnierzom poległym na froncie. „Żołnierz umierający na polu walki nie jest męczennikiem w znaczeniu ścisłym i teologicznym - napisał kardynał D. J. Mercier w swoim słynnym liście pasterskim o patriotyzmie i przetrwaniu na Boże Narodzenie 1914 r. - ponieważ umiera $\mathrm{z}$ bronią $\mathrm{w}$ ręku, podczas gdy męczennik oddaje się przemocy oprawców bez stawiania oporu. Jeżeli jednak zapytacie, co myśleć o zbawieniu wiecznym bohatera świadomie oddającego życie, by bronić honoru ojczyzny i pomścić naruszoną sprawiedliwość, to odpowiadam bez najmniejszej wątpliwości, że Chrystus nagradza bohaterstwo żołnierskie i śmierć

32 Rackl, Ist der Tod fürs Vaterland ein Martyrium?. Tenże, Die Anschauung der katholischen Theologen über das Martyrium des Soldatentodes, ss. 145-150.

${ }_{33}$ Kranich, Ist Kriegertod Märtyrertod?, Ss. 2-5; 15-20; 23-27; 35-38.

34 Pohle, Soldatentod und Märtyrertod.

35 Rackl, Die Anschaunng der katholischen Thelogen über das Martyrium des Soldatentodes, ss. 149-150. Tenże, Ist der Tod fürs Vaterland ein Martyrium, ss. 1-9; 24-30; 35; 39; 40-41. - Kranich, Ist Kriegertod Märtyrertod?, s. 37. Pohle, Soldatentod und Märtyrertod, ss. 32 n.; 129.

36 S. Thomas, Sum. Theol., 11-11, q. 124, a. 5, ad 3. - Wypada jednak zauważyć, że teologowie odrzucający możliwość męczeństwa na polu walki odwołują się również do autorytetu św. Tomasza z Akwinu. Kranich, Ist Kriegertod Märtyrertod?, s. 18.

37 E. Stauffer, Märtyrertheologie und Täuferbewegung, w: Zeitschrift für Kirchengeschichte, 52 (1933) 553.

38 A. Michel, La guerre et le martyre d'après saint Thomas d'Aquin, w: Revue pratique d’apologétique, 25 (1917) $82-83$. 
po chrześcijańsku przyjętą, zapewnia żołnierzowi zbawienie duszy" 39. Kardynał L. Billot ${ }^{40}$, Y. de la Brière ${ }^{41}$, P. Allard ${ }^{42}$, są tego samego zdania. Za stanowiskiem pełnym rezerwy opowiada się także D. J. Saunders pod koniec drugiej wojny światowej, w dyskusji nad tym zagadnieniem w Stanach Zjednoczonych ${ }^{43}$.

Owo męczeństwo krzyżowców - jak twierdzi H. F. von Campenhausen - jest czymś nowym i typowym dla wieków średnich ${ }^{44}$. Dla H. Doergensa przypisanie męczeństwa poległym żołnierzom ma być konsekwencją fałszywej metody stosowanej przez św. Tomasza z Akwinu. Pomijając z gruntu historyczny charakter terminologii męczeńskiej ma on zajmować pozycję ekstremistyczną, tzn. badać ją i interpretować wyłącznie na sposób spektulatywny i racjonalny. Z tego względu prawdziwą ideę męczeństwa można znaleźć jedynie u Ojców Kościoła ${ }^{45}$. Czy ma się tutaj do czynienia również z wpływami religii muzułmańskiej, czyli po prostu powtórzeniem idei islamistycznej o śmierci żołnierzy poległych w wojnie świętej $\mathrm{z}$ niewiernymi, jak to chciałby $F$. Dornseiff ${ }^{46}$, jest rzeczą wielce wątpliwą ${ }^{47}$. W każdym razie Kościół zawsze odrzucał sugestię kanonizowania żołnierzy $z$ tytułu ich męczeńskiej śmierci na polu walki. Czy są oni nimi wobec Boga? Jest to tajemnica, której rozwiązania nie dadzą chyba nigdy rozważania i dyskusje teologiczne.

\section{II.}

W rozważaniach o pochodzeniu chrześcijańskiej idei męczeństwa będzie chodziło o przebadanie jej źródeł. W tej kwestii istnieje potrójna możliwość. Może ona być wyłączną własnością chrześcijaństwa, lub też pochodzić od innych religii, pogańskich czy żydowskiej. H. F. von Campenhausen broni oryginalności pierwotnej chrześcijańskiej idei męczeństwa, ale istnieją i inne opinie, które starają się wykazać zależność jej bądź to od religii pogańskich, bądź to od judaizmu. Nie ulega wreszcie

39 D. J. Mercier, Patriotisme et endurance, Paris, 1914, ss. 20-21. - Tłumaczenie własne.

${ }_{40} \mathrm{Y}$. de la Brière, Luttes de l'Église et luttes de la patrie (Troisième série: Luttes présentes de l'Église, Août 1914 - Décembre 1915), Paris 1916, s. 361, przyp. 1. - Allard, Martyre, s. 338.

${ }_{41}$ De la Brière, Luttes de l'Église et luttes de la patrie, ss. 357-376.

42 Allard, Martyre, ss. 337-339.

43 Saunders, The Supernatural Value of a Soldier's Death, s. 50.

44 Campenhausen, Die idee des Martyriums in der alten Kirche, ss. 174-175, przyp. 6.

${ }_{45} \mathrm{H}$. Doergens, Zur Geschichte des Begriffes „Martyr”, w: Der Katholik, 21 (1918) 205-208.

46 Dornseiff, Der Märtyrer: Name und Bewertung, ss. 151-153.

47 C. Erdmann, Die Entstehung des Kreuzzugsgedankens (Forschungen zur Kirchen- und Geistesgeschichte, 6), Stuttgart, 1935, ss. 27-28 - W. Björkmann, Shahid, w: Handwörterbuch des Islam, Leiden, 1941, s. 663. - H. Dörrie, Märtyrer, w: Die Religion in Geschichte und Gegenwart, 4 ( $\left.{ }^{3} 1960\right) 588$. 
najmniejszej wątpliwości, że cokolwiek powie się o wspomnianych twierdzeniach w ich całości, trzeba uznać w chrześcijańskiej idei męczeństwa elementy oryginalne, zwłaszcza jej charakter chrystocentryczny, który zakłada specjalny związek męczennika z Chrystusem. Właśnie ta problematyka stanowić będzie przedmiot naszych dalszych rozważań.

\section{OPINIA H. F. VON CAMPENHAUSENA}

Zdaniem H. F. von Campenhausena idea męczeństwa zawdzięcza swe pochodzenie chrześcijaństwu ${ }^{48}$. W rzeczywistości nie znajdujemy jej w innych religiach i innych filozofiach. Twierdząc tak, ma on na myśli pierwotną ideę męczeństwa, tzn. tę, która znajduje się w Ewangeliach synoptycznych i u św. Pawła.

Najpierw należy wykluczyć wpływ hellenistyczny, ponieważ uwidacznia się on w okresie znacznie późniejszym i w pojęciu męczeństwa już zniekształconym, a nie ma miejsca w początkach chrześcijaństwa. W tym ujęciu męczennik jest wcieleniem i uosobieniem wszystkich cnót ${ }^{49}$.

Również Stary Testament i judaizm nie wchodzą tu w grę, ponieważ ich pojęcie męczeństwa różni się całkowicie od chrześcijańskiego. Męczennik żydowski pozostaje tylko wierny prawu i posłuszny przykazaniom Bożym, podczas gdy męczeństwo chrześcijańskie polega na konkretnym nakazie głoszenia Jezusa, tzn. jego życia, przepowiadania i śmierci. Męczennik żydowski nie miał specjalnej misji świadczenia o wydarzeniach historycznych, która posiada decydujące znaczenie w męczeństwie chrześcijańskim. Wyłącznie wyznawcy Pana ją posiadają ${ }^{50}$.

Dowody dla poparcia swej opinii znajduje H. F. von Campenhausen w gminie pierwotnej, tzn. w Ewangeliach synoptycznych i u św. Pawła, albowiem przepowiadanie i cierpienie pozostają tam $\mathrm{w}$ bliskim związku ${ }^{51}$. Przez wysłanie na misje (Mt 10) Jezus powierzył swoim uczniom głoszenie orędzia eschatologicznego, które przyniósł i którego sam był znakiem. „Idźcie i głoście: Bliskie już jest królestwo niebieskie” (Mt 10, 7). Uczniowie jednak natkną się na liczne przeszkody i będą prześladowani. W tej sytuacji powinni oni zostać wierni aż do śmierci. „Nie bójcie się tych, którzy zabić mogą ciało, lecz duszy zabić nie mogą. Bójcie się raczej tego, który duszę i ciało może zatracić w piekle"

48 Campenhausen, Die Idee des Martyriums in der alten Kirche, s. 1. - Por. Recenzja dzieła H. F. von Campenhausena, Die Idee des Martyriums in der alten Kirche, w: Theologisches Literaturblatt, 62 (1937) 141-144. - O. Casel, Altchristliche Liturgie bis auf Konstantin d. Gr., w: Archiv für Liturgiewissenschaft, 1 (1950) 340-345. - Esking, Das Martyrium als theologisch-exegetisches Problem, s. 229. *y Campenhausen, Die Idee des Martyriums in der alten Kirche, ss. 2; 152-156.

50 Tamże, ss. $2-5$.

51 Tamże, ss. 5-20. 
(Mt 10, 28). Według H. F. von Campenhausena słowa Chrystusa, jeżeli się je weźmie w całości, nie żądają śmierci fizycznej. Nie czynią one również rozgraniczenia wyraźnego pomiędzy męczennikami i resztą wiernych, bo wszyscy są posłanymi, wszyscy razem należą do wyznawców, którym nie wolno zaprzeć się Jezusa Chrystusa ${ }^{52}$. Co więcej! Idea mocy tkwiącej w męczeństwie, która przyciąga i usprawiedliwia, jest. również $\mathrm{w}$ nich nieobecną ${ }^{53}$. Te same idee - powiada H. F. von Campenhausen - znajdują się u św. Pawła, w którego nauce także nie ma jeszcze pojęcia męczeństwa $w$ pełnym znaczeniu ${ }^{54}$. Był on przede wszystkim misjonarzem. Przepowiadanie dobrej nowiny stało się dlań na pewnym etapie życia koniecznością wewnętrzną. „Nie jest dla mnie powodem do chluby to, że głoszę Ewangelię. Odczuwam bowiem ciążącą na mnie koni czność. Biada mi, gdybym nie głosił Ewangelii”. (I Kor 9, 16). Z tej też racji całe życie św. Pawła było jednym wielkim męczeństwe m. Swym sposobem postępowania i przepowiadania, polegającym na całkowitym obumarciu dla siebie, głosił Chrystusa ${ }^{55}$. Smierć nie stanowi zatem w myśli św. Pawła jedynego środka świadczenia. Ponadto, chociaż idea śmierci razem z Chrystusem pozostaje u niego $\mathrm{w}$ łączności $\mathrm{z}$ cierpieniami przyniesionym przez prześladowania, nie ma ona jednak żadnego odniesienia do rzeczywistej śmierci męczeńskiej ${ }^{56}$. W konsekwencji śmierć fizyczna jako szczególna forma świadczenia obca jest pierwotnej idei męczeństwa znanej Synoptykom i św. Pawłowi ${ }^{57}$.

Wydaje się jednak, że opinia H. F. Campenhausena nie da się utrzymać w całej swojej rozciągłości. Z jednej strony trzeba bowiem uwypuklić różnicę pomiędzy męczennikami chrześcijaństwa i herosami starożytności, a $z$ drugiej strony nie wolno zapominać, że chrześcijańska idea męczeństwa tkwi korzeniami w Starym Testamencie i judaizmie.

\section{MOŻLIWOŚĆ POCHODZENIA HELLENISTYCZNEGO}

Chodzi tutaj o zbadanie zagadnienia, czy pogaństwu znane było męczeństwo lub inaczej, czy można mówić o męczennikach filozofii.

Pierwszym, który usiłował wykazać wpływy filozoficzne na chrześcijańskie pojęcie męczeństwa był J. Geffcken. Jego zdaniem filozofia starożytna miała swoich męczenników, np. Sokratesa, którego zarówno w literaturze pogańskiej dotyczącej męczeństwa, jak i w Aktach mę-

\footnotetext{
52 Tamże, ss. 9; 17-19.

53 Tamże, s. 7.

54 Tamize, ss. $10 ; 12-13$.

55 Tamże, s. 14.

56 Tamże, s. 17.

57 Tamże, s. 20.
} 
czeństwa chrześcijan stawiano za wzór ${ }^{58}$. Ale przede wszystkim Epiktet, również filozof, był mędrcem, który odnosił się z pogardą do cierpienia, a nawet śmierci i w jego Rozmowach należy szukać początków prototypu męczennika (den Ursprung des Begriffes, das Urbild von des Märtyrers Wesen) ${ }^{59}$. Należałoby zatem przyjąć, że męczennik stoicki jest prekursorem męczennika chrześcijańskiego. Stąd E. Geffcken wyciąga prosty wniosek, że Akty męczeństwa chrześcijan są wzorowane na opowiadaniach poświęconych bohaterom pogańskim ${ }^{60}$.

Ta opinia została rozwiniętą i poszerzoną przez $R$. Reitzensteina, który w zasadzie powtarza twierdzenia F. Geffckena. Po opisaniu kilku paralel hellenistycznych mających podobieństwo z męczeństwem chrześcijan, R. Reitzenstein prosi jedynie czytelnika, by je osobiście porównał i w ten sposób mógł odkryć podobne pojęcia, u podstaw których leży nie tylko wspólne słowo, lecz również ta sama idea fundamentalna, dające odpowiedź na wszystkie kwestie szczegółowe ${ }^{61}$.

Podobne przedsięwzięcie $\mathrm{w}$ tym kierunku, chociaż to nie było jego pierwszoplanowym celem, przedstawia artykuł H. A. Fischela zatytułowany Martyr and Prophet ${ }^{62}$. Zakładając możliwość wzajemnych wpływów pomiędzy różnymi religiami na terenie imperium rzymskiego ${ }^{63}$ dostrzega on oznaki podobieństwa pomiędzy prorokami i męczennikami żydowskimi jak i chrześcijańskimi $\mathrm{z}$ jednej oraz bohaterami greckimi $z$ drugiej strony ${ }^{64}$. Według Fischela nadzwyczajne zjawiska w naturze w momencie śmierci bohatera były oznaką zagniewania bogów. Nierzadko zjawiska te są zastępowane głosami niebiańskimi. Coś podobnego przedstawia nagła kara, która spotyka imperatora rozkazującego zabić męczennika. Na wzór bogów greckich męczennicy zarówno żydowscy jak i chrześcijańscy są piękni. Sławi się też ich wiek, powagę, a nawet przypisuje im się godność i funkcje aniołów ${ }^{65}$.

Odnośnie do powyższych hipotez należy wraz z innymi autorami stwierdzić, że ani J. Geffcken, ani R. Reitzenstein, ani nikt inny nie dowiódł pochodzenia chrześcijańskiej idei męczeństwa ze źródeł pogań-

58 J. Geffcken, Die Christlichen Martyrien, w: Hermes, 45 (1910) 493-494.

59 Tamże, s. 496.

60 Tamże, s. 497.

61 R. Reitzenstein, Historia monachorum und historia lausiaca. Eine Studie zur Geschichte des Mönchtums und der frühchristlichen Begriffe Gnostiker und Pneumatiker (Forschungen zur Religion und Literatur des A. und des. N. Testaments, 24), Göttingen, 1916, ss. 85-88; 257. Tenże, Bemerkungen zur Martyrienliteratur. 1. Die Bezeichnung Märtyrer, s. 454.

62 H. A. Fischel, Martyr and Prophet, w: The Jewish Quarterly Review, 37 (1947) 265-280; 363-386. - Por. Asting, Die Verkündigung des Wortes im Urchristentum, ss. $699-705$.

63 Fischel, Martyr and Prophet, s. 269.

64 Tamże, ss. $382-383$.

65 Tamże, ss. 376-382. - Por. N. Brox, Zeuge und Märtyrer. Untersuchungen zur frühchristlichen Zeugnis-Terminologie (Studien zum Alten und Neuen Testament, 5), München, 1961, ss. 164; 166-171. 
skich ${ }^{66}$. Przekonywującą natomiast odpowiedź dają dokumenty starożytności odnoszące się do niniejszego problemu. Dadzą się one podzielić na dwie grupy: pierwsza nosi nazwę Akt pogańskich męczeństwa ${ }^{67}$, do drugiej należą Rozmowy Epikteta ${ }^{68}$.

Akta pogańskie męczeństwa opisują rozmaite procesy, mające miejsce w Rzymie w obecnośei cesarza, w których oskarżeni, którym usiłuje się nadać godność męczeństwa, byli Grekami z Aleksandrii posądzonymi o akty gwałtu wobec Żydów ${ }^{69}$. Pomimo mylących pozorów - powiada H. Musurillo - nie są oni męczennikami w sensie religijnym tego słowa, ponieważ wychwalane są u nich: sława miasta i prawa Greków, miłość ojczyzny, życie i wychowanie greckie, by przeciwstawić je wadom i rozwięzłym obyczajom Rzymian ${ }^{70}$. Bohaterów swoich Akta pogańskie męczeństwa ukazują zatem jako przywódców antyżydowskiej partii politycznej o duchu hellenistycznym. Różnica więc między męczennikami chrześcijańskimi, którzy umierają za wiarę w Jezusa Chrystusa, stanowiącą najgłębszą treść ich przekonań, a „męczennikami” hellenistycznymi jest uderzająca i oczywista. Studium Akt pogańskich męczeństwa pozwala co najwięcej - zdaniem H. Musurilla - bliżej określić źródła akt i innych opisów męczeństw w chrześcijaństwie ${ }^{71}$. Dzisiaj nie ulega już wątpliwości, że zaczerpały one stamtąd swój rodzaj literacki - i to jest wszystko, wszelki inny wpływ należy odrzucić 72 .

W Rozmowach Epikteta niewątpliwie można odnaleźć pewne podobieństwo pomiędzy filozofem stoickim i męczennikiem chrześcijańskim. Punkty styczne jednak - jak zauważa słusznie N. Brox - nie są znaczne. W jego ujęciu tak by można je streścić. Tu i tam świadkowie tworzą specjalny stan. Filozof jest powołany przez Boga i uznany przezeń za godnego swej funkcji i misji specjalnej. To też przypomina trochę męczenników chrześcijańskich. Z jednej i drugiej strony pojęcie świadectwa ma charakter religijny. Konflikt $\mathrm{z}$ tyranem $\mathrm{u}$ obu jest spowodowany przez wierność swemu powołaniu. Jednakże motywy, które skłaniają świadka do wierności są bezwzględnie różne - i to jest

66 H. Delehaye, Sanctus. Essai sur le culte des saints dans l'antiquité (Subsidia hagiographica, 17), Bruxelles, 1927, ss. 96-100. - M. Viller, Martyre et perfection, w: Revue d'ascétique et de mystique, 6 (1925) 6. - Dörrie, Märtyrer, s. 588. - Brox, Zeuge und Märtyrer, ss. $18 ; 152 ; 159-160 ; 175-179 ; 189-192$.

67 Acta Alexandrinorum (Bibliotheca scriptorum graecorum et romanorum teubneriana), wyd. H. Musurillo, Lipsiae, 1961. - Por. H. Delehaye, Les Passions des martyrs et les genres littéraires, Bruxelles, 1921, ss. 175-178.

68 Epictète, Entretiens (Collection des Universités de France), texte établi et traduit par J. Souilhé avec la collaboration de A. Jagu, I (Paris, 1948); II (Paris, 1949); III (Paris, 1963); IV (Paris, 1965).

69 Delehaye, Les passions des martyrs, ss. 161-168. - Brox, Zeuge und Märtyrer, ss. 175-176. - Musurillo, Acta Alexandrinorum, ss. VII-IX.

70 Musurillo, Acta Alexandrinorum, s. VIII.

i1 Tamże, s. VIII.

72 Brox, Zeuge und Märtyrer, s. 176. - Delehaye, Les Passions des martyrs, ss. $168-182$. 
decydujące. Filozof występuje z mądrością stoicką rozumianą jako wola Zeusa. Męczennik wyznaje wiarę w Jezusa Chrystusa i Jego obietnice ${ }^{73}$. Filozof stoicki lub cynik nie są nigdzie powołani, aby świadczyć o prawdzie jakiegoś faktu, z którym się zapoznali, ani nie znajdują się wobec: dylematu doktryna albo życie. Po prostu praktykując cnotę i uzgadniając swe czyny ze swoją wolą poddają się zamiarom Boga, choćby za cenę osobistego dobra i wolności, i na tej drodze stają się wzorem, który Bóg może zaproponować innym ludziom do naśladowania ${ }^{74}$. Filozoficzne pojęcie męczeństwa naszkicowane przez Epikteta nie przekracza. więc ram filozofii stoickiej. I $\mathrm{z}$ tego też powodu należy je rozumieć w granicach jej idei 75 .

W konkluzji - abstrahując rzecz zrozumiała od judaizmu, gdzie pojawiły się pierwsze zarysy pojęcia męczeństwa i od islamu, w którym idea męczeństwa mając wspólne korzenie historyczne rozwijała się równolegle $z$ idea chrześcijańską - należy się podpisać pod tym, co zauważa na ten temat $H$. Dörrie, a mianowicie, że religie niechrześcijańskie nie miały idei męczeństwa podobnej do chrześcijańskiej, i to z dwóch względów:

1) Żadna religia pogańska nie wymagała od swych zwolenników wiary absolutnej, bo żadna nie pretendowała do ważności ekskluzywnej i oddania całkowitego. Wszystkie przyznawały się do braków, zgadzały się na to, co inne głosiły. Żadnemu łacinnikowi nawet nie przyszło na myśl, aby skrócić swe życie celem przeszkodzenia uznaniu bogów greckich w Italii. Również żaden Celt nie przelałby kropli krwi, by przeszkodzić instalacji bogów grecko-rzymskich w Galii ${ }^{76}$.

2) Religijność grecka opierała się na zupełnie innych podstawach niż chrześcijańska. Dzieła bogów, ich istnienie, były dla niej zrozumiałe. W rezultaacie nie żądała ona ani wiary, ani obowiązku świadczenia. Stąd śmierć bohaterów starożytności nie nosiła w sobie znamion świadczenia na podobieństwo świadectwa chrześcijan. Nic tam nie przypominało potwierdzenia niezłomnego, głębokiego i rozumnego faktu czy jakiejś doktryny ${ }^{77}$.

Wszystko to, co starożytnść pogańska wniosła w ideę męczeństwa, a co można by określić jako dalsze przygotowanie do niej, sprowadza się do szacunku dla śmierci ludzkiej i niezłomnej postawy wśród przeciwieństw, nauczanych $\mathrm{w}$ różnych szkołach filozoficznych ${ }^{78}$.

73 Brox, Zeuge und Märtyrer, s. 190. - Por. tami̇e, ss. 178-182; 189-192. Delehaye, Sanctus, ss. 96-100.

74 Delehaye, Sanctus, ss. 98-99.

75 Brox, Zeuge und Märtyrer, s. 181.

76 Allard, Dix leçons sur le martyre, s. 2.

77 Tamże, s. 2.

78 Dörrie, Märtyrer, ss. 587-588. Należy również wykluczyć wpływ kultu, którym obdarzano bohaterów w starożytności, na chrześcijański kult męczenników. 


\section{3. ŹRÓDEA ŻYDOWSKIE IDEI MĘCZEÑSTWA}

Czy można znaleźć ideę męczeństwa w świecie żydowskim?

Odpowiedź brzmi pozytywnie: religia żydowska miała swoich męczenników. Pierwszym był Sługa Jahwe należący do figur eschatologicznych (Iz 42,1-4;49,1-6;50,4-9;52, 13-53,12) ${ }^{79}$. Najbardziej zaś znanymi męczennikami żydowskimi są Machabejczycy. Spotkać ich można również w późniejszym judaizmie ${ }^{80}$. Ze względu na ilość męczenników niektórzy autorzy nazywają nawet religię żydowską religią męczeństwa ${ }^{81}$.

Wpływu żydowskiego na chrześcijańską ideę męczeństwa nie da się zakwestionować. Domaga się go choćby ciągłość obu Testamentów. Już zwykłe używanie ksiąg Starego Testamentu w gminach chrześcijańskich wystarczyłoby, pominąwszy teksty wyraźne, że przykład męczenników żydowskich nie pozostał bez reperkusji na męczenników chrześcijańskich ${ }^{82}$. Jak zatem wygląda linia, która łączy żydowską i chrześcijańską ideę męczeństwa? Wiele refleksji na ten temat nasuwa przede wszystkim postawa chrześcijaństwa, jaką zajęło ono w stosunku do męczenników żydowskich. Następnie należy uwzględnić wartość zadośćczyniącą i zasługującą ich ofiary. Wreszcie rodzaj świadectwa oddanego przez męczenników żydowskich powinien być bliżej zbadany.

Wiadomo, że Kościół pierwotny uznał męczenników żydowskich, w szczególności Machabejczyków, za swoich; w Antiochii np. chrześcijanie zajęli nawet grób Machabejczyków. Z tego też powodu Żydzi w okresie późniejszym muszą się go zrzec ${ }^{83}$. Warto na tym miejscu zapytać, dlaczego Kościół to uczynił i jakie motywy skłoniły go do tego kroku. Jak argumentowano, gwoli usprawiedliwienia, bądź co bądź dość niezwykły fakt? Ten interesujący problem zbadał ostatnio bliżej

T. Klauser, Christlicher Märtyrerkult, heidnischer Heroenkult und spätjüdische Heiligenverehrung. Neue Einsichten und neue Probleme, w: Arbeitsgemeinschaft für Forschung des Landes Nordrhein-Westfalen, Bd. 16 (Köln-Opladen, 1960), ss. 35-37. - Por. H. Delehaye, Les origines du culte des martyrs, Bruxelles, ${ }^{21933,}$ Ss. $404-417$.

79 A. Gelin, Les origines bibliques de l'idée de martyre, w: Lumière et vie, 36 (1958) 123-124. - E. Lohmeyer, L’idée du martyre dans le Judaïsme et dans le Christianisme primitif, w: Revue d'histoire et de philosophie religieuses, 7 (1927) $317-319$.

80 Surkau, Martyrien in jüdischer und frühchristlicher Zeit, ss. 9-82. - Brox, Zeuge und Märtyrer, ss. 155-166.

81 W. Bousset-H. Gressmann, Die Religion des Judentums im späthellenistischen Zeitalter (Handbuch zum Neuen Testament, 21), Tübingen, 1926, s. 374.

82 Hocedez, Le concept de martyr, s. 96.

83 E. Lohse, Märtyrer und Gottesknecht. Untersuchungen zur urchristlichen Verkündigung vom Sühntod Jesu Christi (Forschungen zur Religion und Literatur des A. und des N. Testaments, 64), Göttingen, ${ }^{2} 1963$, s. 72. - Inny przykład przywłaszczania sobie przez Kościół grobów i relikwi czczonych u Żydów dostarcza ostatnio odnaleziony tekst gruziński o trzech Młodzieńcach z Babilonii: G. Garitte, L'invention des Trois Enfants de Babylone, w: Le Muséon, 72 (1959) 69-100. 
T. W. Manson; przede wszystkim zapoznał się on z dyskusją Ojców Kościoła na ów temat (Ignacy Antiocheński, Ireneusz, Cyprian, Orygenes, Augustyn). Zdaniem jego tradycja patrystyczna uznawała bohaterów Starego Testamentu za świadków Chrystusa. W oczach pierwotnego Kościoła oni również zmarli za Jezusa ${ }^{84}$. Bez wątpienia te poglądy musiały stworzyć stosunek zależności pomiędzy koncepcją żydowską i chrześcijańską męczeństwa, szczególnie widoczną w kulcie męczenników ${ }^{85}$.

Podobne zjawisko można stwierdzić i gdzie indziej, mianowicie w przypisywaniu przez religlię żydowską i chrześcijaństwo śmierci męczeńskiej wartości oczyszczającej i zasługującej ${ }^{86}$. Z całą pewnością zachodziła różnica zdań u Żydów w tej kwestii, choćby dlatego, że judaizm późniejszy uważał męczeństwo za karę za grzechy. Łączność pomiędzy grzechem i męczeństwem nie była jednak uznawana przez rabinów. Ostatecznie wszyscy byli jednomyślni odnośnie do wielkiej wartości moralnej męczeństwa - w szczególności przypisywano mu moc zasługującą. Męczennicy mieli zasługiwać dla siebie i dla ludu na łaskę i błogosławieństwo Boże ${ }^{87}$. Tę samą ideę można również odnaleźć w martyrologii chrześcijańskiej. Zdaniem E. Petersona w Kościele pierwotnym męczenników uważano za posiadaczy parrhesia. Była ona podwójna: jedna na ziemi, druga w niebie. Tutaj, na ziemi, uwidaczniała się parrhesia w godnej i nieugiętej postawie męczenników względem wrogów wiary. Po śmierci natomiast męczennicy idą prosto do nieba. Widzą oni Chrystusa przed innymi chrześcijanami. To, co wierni zdobędą, i to tylko prawdopodobnie w dzień ostateczny, męczennicy posiadają z całą pewnością natychmiast. Więcej nawet - należą do „przyjaciół Bożych”. Mogą Boga o wszystko prosić i faktycznie modlą się za żywych. Właśnie $\mathrm{z}$ tego względu słowo parrhesia stało się u Greków pojęciem centralnym w nauce o wstawiennictwie męczenników, a następnie świętych w ogóle ${ }^{98}$. Zależność wzajemna jest więc oczywista. Dostrzegł ją już D.A.Schlatter ${ }^{89}$. W sformułowaniu E. Lohse najbardziej widoczna staje się $w$ tym, co zostało powiedziane, tzn. że $\mathrm{w}$ wierze chrześcijańskiej męczennik

84 T. W. Manson, Martyrs and Martyrdom, w: Bulletin of the John Rylands Library, 39 (1956-1957) 479; 483.

$85 \mathrm{~J}$. Jeremias, Heiligengräber in Jesu Umwelt (Mt 23, 29; Lk 11, 47). Eine Untersuchung zur Volksreligion der Zeit Jesu, Göttingen, 1958. - Klauser, Christlicher Märtyrerkult, heidnischer Heroenkult und spätjüdische Heiligenverehrung, ss. 34-35. - D. A. Schlatter, Der Märtyrer in den Anfängen der Kirche (Beiträge zur Förderung christlicher Theologie, 19), Gütersloh, 1915, s. 27.

86 Lohse, Märtyrer und Gottesknecht, ss. 67-78; 203-210. - E. Stauffer, Die Theologie des Neuen Testaments, Gütersloh, ${ }^{4} 1948$, s. 317.

87 Surkau. Martyrien in jüdischer und frühchristlicher Zeit, s. 138. - Lohse, Märtyrer und Gottesknecht, ss. 66-78.

88 E. Peterson, Zur Bedeutungsgeschichte von Parrhesia (Sonderdruck aus der Reinhold-Seeberg-Festschrift), Leipzig, 1929, s. 294. - Por. tamże, ss. 292-293. Campenhausen, Die Idee des Martyriums in der alten Kirche, s. 89, przyp. 1.

89 Schlatter, Der Märtyrer in den Anfängen der Kirche, s. 32. 
nie czeka w otchłani na sąd ostateczny, ponieważ Żydzi także wierzyli w tę prawdę. Chrześcijaństwo zmodyfikowało ją tylko nieco dorzucając, że śmierć realizuje pobyt i unię z Jezusem Chrystusem ${ }^{90}$. W ten sposób została otwarta szeroko brama na wpływ koncepcji żydowskich w chrześcijańskiej teologii męczeństwa ${ }^{91}$.

Problem świadectwa, które złożyli męczennicy żydowscy należy chyba do najbardziej dyskusyjnych. Istota zagadnienia polega $\mathrm{w}$ odpowiedzi na pytanie, czy ich cierpienie i ich śmierć są prawdziwym świadectwem oddanym na potwierdzenie wiary, czy też nie oznaczają po prostu zwykłej wierności prawu Starego Testamentu. Chodzi mianowicie o to, aby sprawdzić, czy chrześcijańskie pojęcie męczeństwa stosuje się w mniejszym lub większym stopniu do mordowanych Żydów, czy zachodzi zgodność lub rozbieżność idei w tym względzie. Autorzy nie są zgodni co do tego. Odpowiedź pozytywna wydaje się być bardzo prawdopodobna, dlatego trzeba przytoczyć kilka opinii bardziej charakterystycznych.

Najgłośniejszy i znany w tej sprawie jest chyba pogląd E. Lohmeyera. Sądzi on, że dwa rodzaje idei spotykają się w pojęciu męczeństwa: idea, która uznaje wartość religijną cierpienia i idea głosząca aktualną konieczność wyznania ${ }^{92}$. Te właśnie idee zdają się być bardzo ściśle i wprost nierozerwalnie złączone u Deutero - Izajasza, twórcy doktryny o męczeństwie $\mathrm{w}$ religii żydowskiej. Izrael bowiem $\mathrm{z}$ przyczyny swego wybraństwa Bożego jest świadkiem Boga (Iz 43, 9); w porównaniu z innymi ludami jest o narodem prześladowanym. Cierpienie Izraela Deutero-Izajasz przedstawia jako niezasłużone i spowodowane jedynie wybraństwem Bożym, które czyni zeń świadka Boga ${ }^{93}$. Stąd losy historyczne i religijne czynią z narodu wybranego świadka, o ile on cierpi i zobowiązują go do cierpienia, ponieważ jest świadkiem. Owa konieczna relacja pomiędzy świadectwem i cierpieniem opiera się więc na metafizyce zakładającej istnienie dwóch światów pozostających w nieustannym konflikcie ${ }^{94}$ i idea świadka suponuje trzy konstytutywne elementy religii żydowskiej: Boga, narody i społeczność ludu wybranego ${ }^{95}$. Z czasem koncepcja ta, stworzona przez Deutero-Izajasza, uległa pewnej modyfikacji, materializacji ${ }^{96}$. Rozpoczęto bowiem uznawać za świadków nie lud jako taki, ale pewne jednostki sprawiedliwych. Cierpieli oni za wiarę i to niekiedy prześladowanie gwałtowne. U nich również wiara implikuje cierpienie, a cierpienie świadczy o wierze. Ponadto

\footnotetext{
so Lohse, Märtyrer und Gottesknecht, s. 204.

91 Tamże, s. 205. - Por. tamże, ss. 203-210.

92 Lohmeyer, L'idée du martyre dans le Judä̈me et dans le Christianisme primitif, ss. $317 ; 326$.

93 Tamże, s. 318.

94 Tamże, s. 318 .

95 Tamże, s. 319 .

s6 Tamże, s. 319 .
} 
unia powyższa jest możliwa tylko pod warunkiem, jeżeli wiara stanowi świadectwo otwarcie atakowane w świecie, lecz zarazem przeznaczone, aby dziedziczyć istnienie chwalebne i nie podlegające dyskusji przy końcu świata. W ten sposób los męczennika reasumuje losy ludu ${ }^{97}$. Jak widać, męczeństwo nabiera tutaj sensu eschatologicznego, ponieważ zapewnia ostateczny triumf i równocześnie implikuje opiekę Bożą. Te same więc trzy potężne elementy, które przez swój wzajemny stosunek tak dobrze charakteryzują religię żydowską, określają równie dobrze rolę religijną męczennika ${ }^{98}$. W przepowiadaniu Jezusa - według E. Lohmeyera - znajdują się bardzo wyraźnie wszystkie składniki konstytutywne z żydowskiej koncepcji męczeństwa. Można by nawet zaryzykować twierdzenie, że entuzjazm pierwotny chrześcijan niejako ją oczyścił i skondensował ${ }^{99}$. Chrystus nauczał, że wszyscy wysłannicy Boga żyjący w przeszłości jak i ci, którzy dopiero nadejdą, byli lub będą prześladowani i zabici (Mt 5, 11-12; 23, 34-35; Hbr 11, 4; 12, 24). Świat z zasady pozostaje w opozycji do głosicieli słowa Bożego 100. Męczennik ma zapewnioną opiekę Bożą, która go w razie potrzeby inspiruje (Mt 10, 18-20). Wreszcie dwa pisma Nowego Testamentu przez swą kompozycję, strukturę, formę i treść, a mianowicie List św. Pawła do Filipian i Apokalipsa św. Jana Apostoła, prezentują bardzo dokładnie tę ideę męczeństwa 101. Na tej drodze chciał E. Lohmeyer znaleźć chrześcijańską ideę męczeństwa w religii żydowskiej ${ }^{102}$.

Również H. W. Surkau, z okazji polemiki z H. F. von Campenhausenem, odnoszącej się do źródeł idei męczeństwa, zadaje sobie pytanie pod adresem tekstów żydowskich: czy pozwalają one swoich bohaterów nazwać świadkami przez krew, męczennikami 103. Odpowiedź wypadła pozytywnie. Idea świadczenia wobec świata spraw Bożych znajduje się już u Deutero-Izajasza (Iz 43, 10; 53); także w tym sensie Machabeusze są nazwani świadkami (4 Mch 12, 17; 16, 16) ${ }^{104}$. Chociaż jest prawdą,

\footnotetext{
97 Tamże, s. 320 .

98 Tamże, s. 324.

99 Tamże, s. 325.

100 Tamże, s. 325.

101 Tamże, s. 327.
}

102 Hipoteza E. Lohmeyera jest mocno krytykowana. E. Hocedez zarzucił jej, że nie ma dla niej podstaw w tekstach biblijnych: „Toute cette synthèse de E. Lohmeyer, si belle ế si élevée, nous apparaît comme une vue de l'esprit, dans le recul de l'histoire, non comme une vue des contemporains; c'est une explication, très vraie sans doute, du rôle d'Israël, mais cette explication n'est pas exprimée dans les textes, rien ne suggère qu'elle fut aperçue par les Juifs: elle est le fruit de la réflexion philosophique de l'auteur", Le concept de martyr, ss. 98-99. - Por. $\operatorname{tam} \dot{z} e$, ss. $80-84 ; 96-99$. - Zdaniem H. F. Campenhausena, E. Lohmeyer ,vermischt weitgehend alle Unterschiede, die zwischen jüdischen, früh-und spätchristlichen 'Martyrien' bestehen", Die Idee des Martyriums in der alten Kirche, s. 3, przyp. 3.

103 Surkau, Martyrien in jüdischer und frühchristlicher Zeit, ss. 135-139.

104 Tamże, s. 136. 
że wierność prawu zajmuje bardzo znaczne miejsce w opowiadaniach żydowskich o męczennikach, to jednak należy podkreślić, że broniąc prawa oddawali oni również Bogu świadectwo. Prześladowany umierając potwierdza wobec nieprzyjaciół rzeczywistość Boga żywego, którym oni pogardzają. Wierność prawu stanowi więc ze strony męczennika wyznanie Boga, za którego składa on wobec świata ofiarę z życia ${ }^{105}$. Twierdzenie H. F. von Campenhausena negujące możliwość męczeństwa również poza religią chrześcijańską zdaniem $\mathrm{H}$. W. Surkau idzie za daleko. W judaizmie można bowiem znaleźć coś, co całkiem słusznie określa się świadectwem krwi, czyli męczeństwem. Kościół pierwotny dzięki wniesionym modyfikacjom wkomponowal je tylko we własne idee ${ }^{106}$.

Podobną opinię reprezentuje T. W. Manson. Uważa on, że cierpienie i śmierć za religię były judaizmowi znane ${ }^{107}$. W pierwszym rzędzie należy tam uznać za męczenników proroków - byli oni świadkami par excellence, tzn. świadkami naocznymi i usznymi $w$ całym znaczeniu tego słowa, ponieważ mówili o rzeczach widzianych i słyszanych w radach Jahwe (the Council of Yahweh). Prorocy właśnie, kiedy świadczyli wobec Izraela o zamiarach Bożych, byli prześladowani, a nawet zabijani ${ }^{108}$. Następnie cały lud izraelski był uważany za świadka Boga. Swoją zmienną egzystencją historyczną potwierdzał on prawdę i sprawdzalność świadectwa proroków, których był odbiorcą ${ }^{109}$. W rezultacie nie ma żadnej istotnej różnicy na temat męczeństwa pomiędzy religiami żydowską i chrześcijańską ${ }^{110}$.

Wreszcie po tej samej linii, tzn. punktów stycznych w kwestii męczeństwa pomiędzy Starym Testamentem i Kościołem, wypowiada się G. von Rad. Widzi on np. łączność cierpienia ze świadczeniem u proroków Daniela i Jeremiasza ${ }^{111}$.

Wszystko to, co zostało powiedziane na temat związków pomiędzy żydowską i chrześcijańską ideą męczeństwa dość wyczerpująco sumują uwagi A. Gelina. Otóż, List do Hebrajczyków (11, 33-38) cytując glo-

105 Tamże, s. 137.

106 Tamże, s. 139. - Uwagi krytyczne odnośnie do teorii H. W. Surkau można znaleźć u P. Devos, Recenzja dzieła H. W. Surkau, Martyrien in jüdischer und frühchristlicher Zeit, w: Analecta Bollandiana, 57 (1939) 136-138. - Brox, Zeuge und Märtyrer, ss. $142-143 ; 146 ; 150-153 ; 164$.

107 Manson, Martyrs and Martyrdom, s. 464.

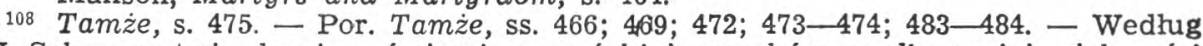
H. J. Schoepsa twierdzenia o śmierci męczeńskiej proroków w olbrzymiej większosci wywodzą się z apokryfów i dlatego nie zawsze pozostają w zgodzie z prawdą: Aus Frühchristlicher Zeit. Religionsgeschichtliche Untersuchungen, Tübingen, 1950, s. 142 .

109 Manson, Martyrs and Martyrdom, ss. 466; 483.

110 Na braki i luki koncepcji T. W. Mansona wskazuje Brox, Zeuge und Märtyrer, s. 145.

111 G. von Rad, Theologie des Alten Testaments, Bd. II: Die Theologie der prophetischen Uberlieferungen Israels, München, 1960, ss. 128-129. 
balnie prześladowania zarezerwowane dla proroków podaje tradycję żydowską odnośnie męczeństwa. Problematyka męczeńska wzięła początek u proroków, następnie została zaakceptowana i rozwinięta szeroko przez Jezusa, św. Szczepana i św. Pawła (Mt 23, 31; Dz 7, 52; 1 Tes 2, 15). $\mathrm{Tu}$ i tam występują te same idee. Zwraca natomiast uwagę na tym etapie brak nazewnictwa odnośnie terminu męczeństwa, który został przez chrześcijan później wypracowany (II w.) ${ }^{112}$.

\section{CHARAKTER CHRYSTOCENTRYCZNY CHRZESCIJAŃSKIEGO MECZEŃSTWA}

W tej sytuacji nasuwa się pytanie, co wnosi do świaddectwa krwi złożonego przez męczenników żydowskich, wiernych prawu, chrześcijańska idea męczeństwa.

Otóż oryginalność chrześcijańskiej koncepcji męczeństwa wyraża się przede wszystkim $w$ jej charakterze chrystocentrycznym ${ }^{113}$. Było już powiedziane wyżej, że przedmiot świadectwa u męczenników chrześcijan stanowi osoba Chrystusa i Jego dzieło - umierali oni, aby potwierdzić ich prawdę. Charakter chrystocentryczny chrześcijańskiej koncepcji męczeństwa uwypukla się więc przede wszystkim w bardzo ścisłym, głębokim, i osobistym związku, jaki zachodzi pomiędzy Chrystusem i męczennikiem. Ten specjalny związek można ując w dwóch słowach: naśladowanie i zjednoczenie.

Całe chrześcijaństwo przepełniała myśl, że męczeństwo jest najdoskonalszym sposobem naśladowania Jezusa. Naśladowanie stało się czynnikiem podstawowym, ideą przewodnią męczeństwa w ujęciu chrześcijańskim, co potwierdzają liczne teksty Pisma św. ( $\mathrm{J} 13,36 ; 21,18 \mathrm{n}$. Ef 5, 2; 1 P 4, 1-19; Ap 14, 3-4). Tak nauczano przez trzy pierwsze wieki, a więc podczas największych prześladowań Kościoła, a i w okresie późniejszym nie przestaje się uważać męczeństwa za najpełniejsze naśladowanie Chrystusa ${ }^{114}$. Nawet społeczności odłączone w czasach Reformacji opowiadały się za tym bez zastrzeżeń ${ }^{115}$. Rzecz zrozumiała, że dla lepszego wniknięcia w tę myśl należy usytuować ją w kontekście nauki o naśladowaniu Jezusa Chrystusa w ogóle ${ }^{116}$. Chrześcijanin jest uczniem

112 Gelin, Les origines bibliques de l'idée de martyre, ss. 128-129. - Opinię przeciwną, tzn. wykluczającą związek pomiędzy świadczeniem i cierpieniami, a nawet śmiercią, u "męczenników" żydowskich reprezentują następujący autorowie: Allard, Dix leçons sur le martyre, ss. 2-3. - Campenhausen, Die Idee des Martyriums in der alten Kirche, ss. 2-5. - Strathmann, Mártys, s. 491. - Brox, Zeuge und Märtyrer, ss. 172-173.

${ }_{113} \mathrm{~L}$. Bouyer, La spiritualité du Nouveau Testament et des Pères (Histoire de la spiritualité chrétienne, 1), Paris, 1960, s. 242.

114 J. Madoz, El amor a Jesucristo en la Iglesia de los mártires, w: Estudios eclesiasticos, 12 (1923) 331-334. - Por. Kubiś, La théologie du martyre au vingtième siècle, ss. $79-80$, przyp. 114.

115 Stauffer, Märtyrertheologie und Täuferbewegung, ss. 564; 570-573.

116 Zob. dwa artykuły o tym samym tytule — "Nachfolge Christi" - z litera- 
- zauważa M. Viller - którego obowiązkiem pozostaje wzorowanie się na Jezusie, swoim Mistrzu; naśladowanie Chrystusa powinno obejmować całe jego życie. W czasach prześladowań będzie ono miało jednak szczególniejszy związek z Jezusem cierpiącym. W nich bowiem męka i śmierć Chrystusa silniej przykuwają uwagę chrześcijan 117. Smierć chrześcijanina dla oddania świadectwa Jezusowi stanowi punkt szczytowy pójścia za Nim i z tego też względu - powiada słuşnie E. Lohmeyer - w przepowiadaniu Chrystusa męka jego i śmierć posiadają tak ogromne znaczenie i zostały opisane jako najdoskonalszy wzór męczeństwa chrześcijańskiego ${ }^{118}$. Jezus Chrystus, „świadek wierny i prawdomówny" (Ap 1, 5; 3, 14), jest prototypem męczennika ${ }^{119}$. W oczach wierzących męczennik na skutek przebytych udręczeń staje obok Chrystusa jako pierwszego męczennika, naśladuje Go i współzawodniczy z Nim ${ }^{120}$. Cierpiąc wespół ze swoim Mistrzem odtwarza w sobie Jego mękę i nosi Jego znamiona. Jest to najgłębsze urzeczywistnienie $z$ Nim wspólnoty egzystencjalnej, jest to również pełnia miłości ${ }^{121}$.

Ten wyjątkowo bliski stosunek ofiary Jezusa i męczennika znalazł może swój najpełniejszy wyraz w zwyczaju sprawowania eucharystii w rocznicę śmierci, czy też przeniesienia relikwii na grobach męczenników; w ten sposób liturgia jak gdyby ustawia obok siebie misterium Chrystusa i misterium męczennika, pragnie podkreślić wzajemną konpenerację tych dwóch rzeczywistości nadprzyrodzonych ${ }^{122}$. Zdaniem O. Casela istniejący między nimi stosunek da się przyrównać do relacji, która zachodzi pomiędzy śmiercią Chrystusa i śmiercią męczenników. Misterium męczenników jest owocem i częścią misterium Chrystusa. Płyną one razem i u podstaw (im Grunde) są czymś jednym. Kult męczenników nie stworzył więc drugiego, niezależnego misterium od misterium Chrystusa, lecz raczej to ostatnie zostało tylko rozbudowane i urzeczywistnione ${ }^{123}$. Innymi słowy msza św. odprawiona na grobie

turą odnoczącą się do przedmiotu, w: Die Religion in Geschichte und Gegenwart, 4 (31960) 1286-1293 i Lexikon für Theologie und Kirche, 7 (21962) 758-764. Sa one napisane przez sześciu różnych autorów: E. Lohse-E. Kähler-N. H. See i A. Schulz-

$-R$. Hoffman-E. Iserloh.

117 Viller, Martyre et perfection, ss. 6-7.

118 Lohmeyer, L'idée du martyre dans le Judaisme et dans le Christianisme primitif, s. 326. - Por. Kranich, Ist Kriegertod Märtyrertod?, ss. 3; 5; 17. K. H. Schelkle, Die Passion Jesu in der Verkündigung des Neuen Testaments.

Ein Beitrag zur Formgeschichte des Neuen Testaments, Heidelberg, 1949, ss. 222-230.

119 Stauffer, Die Theologie des Neuen Testaments, ss. 164-167.

120 Corssen, Begriff und Wesen des Märtyrers in der alten Kirche, ss. 494-496.

121 Schmaus, Katholische Dogmatik, Bd. IV/1, ss. 155; 176; 395; 419; 451; 476. -

M. Pellegrino, L'imitation du Christ dans les Actes des martyrs, w: La vie spirituelle, 38 (1958) 38-54.

122 B. de Gaffier, Réflexions sur les origines du culte des martyrs. w: La Maison-Dieu, 52 (1957) 30-34.

123 O. Casel, Mysterium und Martyrium in den römischen Sakramentarien, w: Jahrbuch für Liturgiewissenschaft, 2 (1922) 29. 
męczennika wskazuje na to, że śmierć jego uczestniczy w wielkości ofiary Chrystusa 124. Całą treść tej prawdy lapidarnie wyraża stara modlitwa liturgiczna, sekreta czwartkowa z trzeciego tygodnia Wielkiego Postu: „Dla uczczenia chwalebnej śmierci Swiętych Twoich składamy $\mathrm{Ci}$, Panie, tę ofiarę, z której wszelkie męczeństwo wzięło swój początek”. Słusznie zatem pisze O. Casel, że każde męczeństwo i w konsekwencji każde misterium męczennika mają za źródło ofiarę Chrystusa, która, liturgicznie rzecz biorąc, jest mszą, misterium Chrystusa ${ }^{\mathbf{1 2 5}}$.

Od naśladowania Jezusa do zjednoczenia z Nim jest tylko nieduży krok. Męczeństwo zawsze uważano za najpewniejszy środek połączenia się z Chrystusem ${ }^{\mathbf{1 2 6}}$, a temat naśladowania odnajduje pełny swój sens dopiero w nadziei ,dotarcia do Chrystusa”, , być znalezionym w Chrystusie" 127. Chodzi tutaj o zjednoczenie męczennika z Chrystusem w sensie bardzo specjalnym. Na ziemi przekracza ono wszelką inną łączność, jaką wierni mogą mieć z Jezusem. Jest ona tak głęboka, że przynosi męczennikowi szczególniejszą obecność Mistrza i wzmacnia go wśród przeciwności - Jezus Chrystus żyje i działa wespół z męczennikiem i w męczenniku ${ }^{128}$. Najdobitniej wiarę powszechną Kościoła wyrażają pod tym względem słowa św. Felicyty, wypowiedziane w następujących okolicznościach: świętą, przebywającą w więzieniu i znajdującą się w bólach porodowych, zapytał strażnik więzienny, co będzie czynić rzucona zwierzętom na męki, skoro obecnie już tak boleje. „Teraz — brzmiała odpowiedź - ja cierpię, lecz tam ktoś inny będzie we mnie, który będzie cierpiał za mnie, bo wówczas i ja za niego cierpieć będę" ${ }^{129}$. Ta właśnie wiara Kościoła sprawiła, że z czasem słowo Christoforos stało się dla męczenników zaszczytnym tytułem. Mimo różnic w interpretacji na Zachodzie i Wschodzie, (Christoforoi = nosiciele Chrystusa) (Christoforos =- przez Chrystusa napełniony, od Logosa uzdolniony), oznaczało ono przede wszystkim obecność umacniającą i zwycięską Jezusa Chrystusa w męczennikach ${ }^{130}$. I rzeczywiście wielu $z$ nich szło na mękę z radością nienawidząc śmierć - torturowani nie odczuwali nawet bólu, śmierci ich towarzyszyły wizje, ekstaza i cuda. Wówczas

124 De Gaffier, Réflexions sur les origines du culte des martyrs, s. 31.

125 Casel, Mysterium und Martyrium in den römischen Sakramentarien, s. 29.

126 Viller-Rahner, Aszese und Mystik in der Väterzeit, s. 33. - Por. Viller, Martyre et perfection, ss. 13-17.

127 Bouyer, La spiritualité du Nouveau Testament et des Pères, ss. 250-256.

128 Viller, Les martyrs et l'Esprit, ss. 544-545. Tenże, Martyre et perfection, ss. 13-17. - Viller-Rahner, Aszese und Mystik in der Väterzeit, ss. 33-36. M. Lot-Borodine, Le martyre comme témignage de l'amour de Dieu, d'après Nicolas Cabasilas, w: Irénikon, 27 (1957) 157-159; 161-163. - Stolz, L'ascèse chrétienne, ss. 130-131. - Lods, Confesseurs et martyrs, ss. 18-22.

129 Passio SS. Perpetuae et Felicitatis 15, 5-6: wyd. C. I. M. I. van Beek, Passio sanctarum Perpetuae et Felicitatis, I (Noviomagi, 1936), ss. $36 ; 38$.

130 F. J. Dölger, Christophoros als Ehrentitel für Martyrer und Heilige im christlichen Altertum, w: Antike und Christentum, 4(1934 75-76. 
Duch Boży i Jezusa nie tylko ich wspierał - zauważa M. Lods - lecz również w nich mieszkał, by mogli triumfować nad swoją słabością ludzką, bojaźnią i niewypowiedzianymi cierpieniami ${ }^{131}$. Jedności męczennika z Chrystusem nie zrywa nawet śmierć. Niebo, które dla wielu, a zdaniem niektórych autorów dla wszystkich długo pozostaje niedostępne, tylko dla męczenników otwiera się bez oczekiwania. Umierając osiągają oni natychmiast Pana 132.

Dobrze streszcza myśli wyrażone powyżej L. Bouyer zauważając, że męczeństwo należy do największych fenomenów charyzmatycznych Kościoła pierwotnego. Nagromadzenie się różnych charyzmatów wokó męczeństwa nie powinno pozwalać na zapomnienie, że ono samo jest największym charyzmatem. Jest nim dlatego, bo realizuje zjednoczenie z Chrystusem-Bogiem i pełnię doskonałej miłości ${ }^{133}$.

\section{III}

Do tych rozważań należy dorzucić jeszcze w charakterze konkluzji, kilka uwag o sensie eklezjalnym męczeństwa, gdyż zajmuje ono w strukturze Kościoła miejsce niezastąpione i bardzo istotne.

Stosunki między męczennikiem i Kościołem są wielorakie. Męczennik wyznaje swą przynależność do społeczności wiernych, modli się i cierpi za Kościół, słowem, a zwłaszcza przykładem zachęca swoich współwyznawców do wytrwania w niebezpieczeństwie. Kościół znowu ze swej strony przygotowuje wiernych do wytrwania głosząc słowo Boże i udzielając sakramentów św. W ten sposób zdobywają męczennicy potrzebne siły do walki. W razie potrzeby Kościół zapewnia męczennikowi, jeżeli jest to możliwe, opiekę aż do ostatecznej próby, grzebie nabożnie jego śmiertelne szczątki, zapisuje jego imię w swych kalendarzach i oddaje mu kult religijny ${ }^{134}$. Należy jednak jeszcze głębiej sięgnąć poza powyższy „fenomenologiczny” opis w określeniu relacji pomiędzy męczennikiem i Kościołem. Zdaniem E. Petersona ${ }^{\mathbf{1 3 5}}$ sytuacja uprzywilejowana męczeństwa w Kościele była przedmiotem przepowiadania eschatolo-

131 Lods, Confesseurs et martyrs, s. 333. - Por. tamże, ss. 29-32. - H. Achelis, Das Christentum in den ersten drei Jahrhunderten, I (Leipzig, 1912), s. 295; II (Leipzig, 1912), ss. $444-445$.

132 J. P. Kirsch, Die Lehre von der Gemeinschaft der Heiligen im christlichen Altertum. Eine dogmengeschichtliche Studie (Forschungen zur christlichen Literatur und Dogmengeschichte, 1), Mainz, 1900, 68-74. - Kattenbusch, Der Märtyrertitel, ss. 116-118. - Achelis, Das Christentum in den ersten drei Jahrhunderten, 11, $349-350$; 441. - Lot-Borodine, Le martyre de l'amour, d'après Nicolas Cabasilas, Ss. $163-165$.

${ }_{133}$ Bouyer, La spiritualité du Nouveau Testament et des Pères, ss. 254; 256.

134 M. Pellegrino, Le sens ecclésial du martyre, w: Revue des sciences religieuses, 35 (1961) 152. - Por. tamże, ss. 156-174.

${ }^{135}$ E. Peterson, Zeuge der Wahrheit (Der Märtyrer und die Kirche), w: Tenże Theologische Traktate, München, 1951, ss. 165-183. 
gicznego w katechezie pierwotnej i uwidacznia się już w pismach Nowego Testamentu 136. Rozważania swoje w tym przypadku opiera on na pouczeniu Jezusa Chrystusa, danym Apostołom przed ich pójściem na misję (Mt 10) 187. Dwa z jego wniosków godne są szczególniejszej uwagi.

A. Według E. Petersona męczeństwo najpierw zakłada specjalne powołanie, jest charyzmatem ${ }^{138}$, tzn. darem duchowym ${ }^{913}$, ponieważ pozycja męczennika w Kościele, jest pozycją człowieka, który przyjął specjalny charyzmat ${ }^{140}$. Jest ono szczególną łaską, bo żaden człowiek nie może go posiąść z własnej inicjatywy i sił ${ }^{141}$. Jako charyzmat, męczeństwo nie musi wiązać się z jakąś funkcją w Kościele. Urząd i charyzmat były złączone tylko u Apostołów; pozycja ich zatem była wyjątkowa. W rezultacie trzeba oddzielić pojęcie męczeństwa od osoby Apostoła jako takiego, chociaż Apostołowie byli również męczennikami ${ }^{142}$. Tezę powyższą uzasadniają dwie racje. Z jednej strony następca apostołów w sensie prawnym słowa nie jest koniecznie ich następcą w cierpieniu, z drugiej strony zaś cierpienia apostolskie mogą spotkać kogoś, kto nie jest jurydycznie następcą apostołów ${ }^{143}$. Z całą pokorą wypada więc tu stwierdzić, że następcy dwunastu Apostołów nie są już Apostołami i że męczeństwo w Kościele jako wyodrębniona kategoria ludzi jest konieczne, jeżeli ma on ưdowodnić nie tylko nauczaniem, lecz również w swoim życiu, że kontynuuje uczestnictwo w charyzmatach apostolskich, których częścią składową było cierpienie i męczeństwo Apostołów ${ }^{144}$.

B. Następnie uważa E. Peterson, że męczeństwo należy organicznie do istoty Kościoła, tzn. z absolutną koniecznośeią, jako część składowa, wchodzi do jego pojęcia ${ }^{145}$. Co to oznacza? Otóż, według E. Petersona prześladowania w Kościele nie są czymś przypadkowym i okazyjnym, nie powodują ich zwykłe nieprozumienie lub pomyłka, tzn. nie można ich przypisać przewrotności i złośliwości ludzkiej. To sam Chrystus przepowiedział swojemu Kościołowi nienawiść i cierpienie od Żydów i pogan. Męczenników stwarza konieczność Boża. Słowa Jezusa: „Czyż

136 Tamże, s. 168 i przyp. 3, s. 220.

137 Tamże, ss. $168-172$.

138 Tamże, s. 181.

139 Ch. Journet, L'Église du Verbe incarné. Essai de théologie spéculative. II.

Sa structure interne et son unité catholique, Paris, 1962, s. 319, przyp. 3.

140 Peterson, Zeuge der Wahrheit (Der Märtyrer und die Kirche), s. 175. Por. Schöllgen, Aktuelle Moralprobleme, s. 469.

141 Peterson, Zeuge der Wahrheit (Der Märtyrer und die Kirche), s. 173.

142 Tamże, s. 175.

143 Tami்e, s. 173.

144 Tamże, s. 174. - Por. O. Michel, Zum Märtyrer-Problem, w: Theologische Blätter, 17 (1938) 88.

145 Peterson, Zeuge der Wahrheit (Der Märtyrer und die Kirche), s. 177. 
Mesjasz nie miał tego cierpieć, żeby tak wejść do swej chwały" (Łk 24, 26) panują nad całą historią Kościoła. I będzie on miał męczenników tak długo, jak długo głoszona będzie światu Ewangelia, tzn. do końca świata. Oczywiste jest, że jedne epoki Kościoła były mniej męczeńskie, inne bardziej, lecz twierdzenie, że były momenty $w$ jego historii bez męczenników równałoby się negacji istnienia Kościoła w tych czasach w ogóle 146. Swiadectwo słowa jest zatem związane ze świadectwem cierpienia nie tylko dzięki zwykłemu zbiegowi okoliczności, ale stanowi rzeczywistość, której istnienie przepowedział sam Chrystus ${ }^{147}$. A prześladowcy? Kim są? Jaki los ich czeka? Nie są to ludzie w ogólności, w sensie abstrakcyjnym, lecz ludzie konkretni, którzy żyją na świecie jako Żydzi i poganie ${ }^{148}$. Stali się oni nieprzyjaciółmi Ewangelii z woli Bożej, aby Bóg w swoim miłosierdziu zlitował się nad jednymi i drugimi ${ }^{149}$.

Niech nam wolno będzie zacytować jeszcze jedną uwagę E. Petersona; tym razem pod adresem napisów nagrobkowych na częśc męczenników, skomponowanych w Rzymie przez papieża Damazego I ${ }^{150}$. Na temat prześladowań Kościoła można wśród nich przeczytać wzruszające słowa: „Kiedy miecz przeszył serce Matki.....”. Matka Chrystusa cierpi z męczennikami, którzy ,dopełniają braki udręk Chrystusa w swoim ciele dla dobra Jego Ciała, którym jest Kościół" (Kol 1, 24), bo sam Jezus w nich cierpi. Czy z tej racji tytuł „Królowej męczenników” nie przysługuje słusznie Maryi, Matce Chrystusa?

\section{RE U M E}

\section{L'IDEE CHRETIENNE DE MARTYRE}

Lans l'article présent nous abordons trois questions.

Nous étudions d'abord le concept de martyre reconnu par l'Église, puis deux cas représentant une extension de ce concept, à savoir le martyre spirituel et la mort des soldats tombés sur le champ de bataille. Or, dans le langage chrétien d'aujourd'hui, le martyr est celui qui a sacrifié sa vie pour le Christ, c'est-à-dire pour une réalité faisant partie de la révélation chrétienne (pour défendre la foi, un droit et l'unité de l'Église, le secret de la pénitence, ou bien une vertu chrétienne, par exemple la chasteté), et que ce concept de témoin par le sang, de la divinité du Christ et de sa religion, soutenu par une force surnaturelle, bien qu'il

\footnotetext{
146 Tami்e, ss. $176 ; 177$.

147 Pellegrino, Le sens ecclésial du martyre, s. 154.

148 Peterson, Zeuge der Wahrheit (Der Märtyrer und die Kirche), s. 177.

149 Tamże, s. 178.

150 Tamże, s. 183.
} 
fût formulé au IIe siècle, constitue jusqu'à présent l'unique concept de martyre reconnu par l'Église pour authentique. Cette idée de martyre est conforme à celle de l'Écriture Sainte. Cela ne signifie pas pourtant qu'il y ait dans l'Écriture Sainte une conception achevée du martyre. Ainsi, du fait que l'Église prenait peu à peu conscience du martyre, il ne s'ensuit pas qu'elle ait renié son idée originelle. L'Église n'a fait que recueillir le fruit d'un travail qui doit se poursuivre au cours des siècles. L'histoire de l'Église connait toutefois des essais d'élargissement du concept de martyre, à savoir le ,martyre spirituel” et le „martyre des soldats chrétiens". Durant les trois premiers siècles, on a parlé déjà de suppléances du martyre en le comparant avec l'ascèse. La préparation au martyre, le martyre de désir, la chasteté va presque égaler le martyre réel et sanglant. Les persécutions finies, la vie monastique est considérée avant tout comme martyre spirituel. Le problème du martyre des soldats tombés au champ d'honneur fut discuté particulièrement au temps de la première guerre mondiale (1914-1918). Les avis des théologiens sont sur ce point très partagés. Les meilleurs travaux allemands, concernant le sujet, considèrent la mort des soldats tombés au champ d'honneur bien sûr à certaines conditions - comme un martyre chrétien au sens propre. En France, le problème préoccupe aussi les théologiens, mais leurs conclusions semblent moins catégoriques.

Nous esquissons ensuite les origines du martyre. Il s'y agit des sources de l'idée martyrologique. En effet, trois possibilité entrent en jeu. Le concept chrétien de martyre peut être issu du christianisme ou bien tirer ses origines d'autres religions, soit païennes, soit juive. Après avoir résumé la conception de $\mathrm{H}$. F. von Campenhausen qui défend l'originité de l'idée primitive chrétienne de martyre, nous mettons en relief deux groupes d'opinions qui, d'une part excluent son origine hellénique, et de l'autre, trouvent ses sources dans l'Ancien Testament et le judaïsme. Des remarques sur le caractère christique du martyre chrétien, supposant une relation spéciale avec le Christ, concluent nos réflexions sur ses origines.

Nous terminons par quelques réflexions sur la place indispensable et presque vitale que tient le martyre dans la structure de l'Église. La plus complète et la plus profonde analyse à ce sujet est fournie par E. Peterson. De son avis le martyre suppose d'abord une vocation spéciale; il est un charisme dans l'Église, c'est-à-dire un don spirituel. En d'autres termes, c'est une grâce particulière de bien, qu'aucun homme ne peut susciter de son propre vouloir. Le martyre, affirme ensuite E. Peterson appartient nécessairement au concept d'Église, c'est-à-dire qu'il en est par un besoin absolu, partie intégrante. En consequence les persécutions dans l'Église ne sont pas un événement fortuit et occasjonel. C'est le Christ qui a prédit à l'Église haine et souffrance de la part des juifs et des païens. Les martyrs sont faits par une nécessité divine. Affirmer qu'il y eut des moments de l'histoire privés de martyrs, c'est nier l'existence même d'une Église à ce moment-là. 